\title{
Comparative electrochemical degradation of the herbicide tebuthiuron using a flow cell with a boron-doped diamond anode and identifying degradation intermediates
}

\author{
Gabriel F. Pereira ${ }^{\mathrm{a}}$, Bianca F. Silva ${ }^{\mathrm{b}}$, Regina V. Oliveira ${ }^{\mathrm{a}}$, Douglas A.C. Coledam ${ }^{\mathrm{a}}$, \\ José M. Aquino ${ }^{a}$, Romeu C. Rocha-Filho ${ }^{a, *}$, Nerilso Bocchi ${ }^{a}$, Sonia R. Biaggio ${ }^{a}$ \\ a Departamento de Química, Universidade Federal de São Carlos, C. P. 676, 13560-970 São Carlos, SP, Brazil \\ ${ }^{\mathrm{b}}$ Instituto de Química de Araraquara, Departamento de Química Analítica, Universidade Estadual Paulista, 14800-900 Araraquara, SP, Brazil
}

A R T I C L E I N F O

Article history:

Received 14 January 2017

Received in revised form 9 July 2017

Accepted 9 July 2017

Available online 11 July 2017

Keywords:

Tebuthiuron electrooxidation

Filter-press reactor

BDD anode

Hydroxylation reactions

Chlorine-mediated oxidation

\begin{abstract}
A B S T R A C T
The electrochemical degradation of tebuthiuron (TBH; $100 \mathrm{mg} \mathrm{L}^{-1}$ ) was carried out under enhanced mass transport conditions (using a flow cell with a BDD anode), while investigating the effect of solution $\mathrm{pH}$, absence and presence of $\mathrm{Cl}^{-}$ions in the supporting electrolyte solution $\left(0.1 \mathrm{~mol} \mathrm{~L}^{-1} \mathrm{Na}_{2} \mathrm{SO}_{4}\right)$, and current density $\left(j=10,30,50 \mathrm{~mA} \mathrm{~cm}^{-2}\right)$ on the herbicide degradation and resulting oxidation intermediates. The enhanced mass transport conditions led to significantly improved performances, comparatively to previous results obtained with a common electrochemical cell. The solution $\mathrm{pH}$ or presence of $\mathrm{Cl}^{-}$ions did not affect the TBH removal rate. However, the COD removal rate, despite being independent of $\mathrm{pH}$, was significantly faster in the presence of $\mathrm{Cl}^{-}$ions, most probably due to false results caused by organochlorinated intermediates. In the absence of $\mathrm{Cl}^{-}$ions in solution, the TBH removal rate increased with $j$, whereas the $C O D$ removal rate was not affected, but significantly increased removal rates were attained in the presence of $\mathrm{Cl}^{-}$ions, most probably because of increased formation of organochlorines. As expected, higher values of the general and mineralization current efficiencies as well as lower energy consumptions per unit $T O C$ mass removed $\left(E C_{T O C}\right)$ were attained at $10 \mathrm{~mA} \mathrm{~cm}^{-2}$; in the absence of $\mathrm{Cl}^{-}$ ions, complete removal of TBH and $80 \%$ removal of $T O C$ were attained with $E C_{T O C}=0.2 \mathrm{~kW} \mathrm{~h} \mathrm{~g}^{-1}$ (less than $1 / 10$ of those for electrolyses using a conventional electrochemical cell). From the identified intermediates, an initial TBH oxidation pathway like those of coupled processes involving photochemistry is expected. Most carboxylic acid intermediates were removed or being removed by the end of the electrolyses (except tartronic acid, which accumulated). As expected, organochlorinated intermediates were identified in the presence of $\mathrm{Cl}^{-}$ions, but were completely removed by the end of the electrolyses. In summary, the electrochemical degradation of TBH in the presence of $\mathrm{Cl}^{-}$ions is not advantageous; no significant improvement in the TBH and TOC removal rates, or in the energy expense, is achieved and the formation of organochlorines is a real possibility.
\end{abstract}

(c) 2017 Elsevier Ltd. All rights reserved.

\section{Introduction}

The worldwide use of synthetic organic compounds in industrial and agricultural activities has considerably increased in the recent decades. Among these compounds, pesticides are of great environmental concern, especially because their use keeps increasing while no remediation technology tested at full scale is available, as noted by Rodrigo et al. [1]. Exposure to pesticides can cause several health problems to humans, especially chronic

\footnotetext{
* Corresponding author.

E-mail address: romeu@ufscar.br (R.C. Rocha-Filho).
}

diseases [2]. As highlighted by Abdessalem et al. [3], soil and waterbodies contamination by pesticides is likely to occur because of their high solubility and low biodegradability. In waterbodies, pesticides can be harmful to the aquatic fauna and flora [4]. As noted by Muneer et al. [5], industrial effluents can be a source of water contamination by pesticides. Thus, treatment technologies need to be developed and used to treat such effluents before disposal to the environment.

Among the methods available to treat contaminated water, electrochemical technology has been used to remove various kinds of organic compounds, such as dyes [6-12], pharmaceuticals [1219], pesticides [1,12,20-23], or plasticizers [24-26]. High levels of 
energy consumption and low current efficiencies can be the main possible drawbacks of this technology; however, if an adequate choice of hydrodynamic conditions, applied current density, and anode material is made, high removal degrees can be attained at relatively low energy expenses. The combination of electrochemical technology with other technologies such as Fenton reactions [27], photocatalysis [28,29], and sonochemistry [30] is an alternative approach often investigated to increase the efficiency of pollutant removal. Among anode materials, boron-doped diamond (BDD) has been successfully used [31-33] to oxidize and mineralize organic pollutants due to the production of quasifree hydroxyl radicals (HO`) from water discharge [34]. Limited mass transport of these pollutants to the BDD anode surface is one drawback, but it can be minimized using flow cells and further optimized with turbulence promoters [35]. Mediated chemical oxidation in the solution bulk is another possible way to improve the electrochemical degradation of organics [32]. This is attained when oxidants such as active chlorine $\left(\mathrm{Cl}_{2}, \mathrm{HOCl}, \mathrm{OCl}^{-}\right)$, peroxydisulfate $\left(\mathrm{S}_{2} \mathrm{O}_{8}{ }^{2-}\right)$, percarbonate $\left(\mathrm{C}_{2} \mathrm{O}_{6}{ }^{2-}\right)$, and perphosphate $\left(\mathrm{P}_{2} \mathrm{O}_{8}{ }^{2}-\right)$ are electrochemically generated from supporting electrolyte solutions containing the $\mathrm{Cl}^{-}, \mathrm{SO}_{4}{ }^{2-}, \mathrm{CO}_{3}{ }^{2-}$, and $\mathrm{PO}_{4}{ }^{3-}$ anions, respectively [32]. In such instances, often no information regarding oxidation intermediates is reported in the literature.

Tebuthiuron (TBH) (1-(5-tert-butyl-1,3,4-thiadiazol-2-yl)-1,3dimethylurea; $\mathrm{C}_{9} \mathrm{H}_{16} \mathrm{~N}_{4} \mathrm{OS}$ ), one of the most widely used pesticides in sugar cane plantations, is considered highly toxic by the Brazilian Health Regulatory Agency (ANVISA) and has been reported as highly persistent in the environment [36]. Since TBH has a high solubility in water $\left(2.3 \mathrm{~g} \mathrm{~L}^{-1}\right)$, it can readily contaminate surface and ground water (see e.g. [37]). TBH degradation has been investigated by different approaches: photo-Fenton [38-42], photocatalysis [7,43], combined photochemical-electrochemical technologies using a DSA ${ }^{\circledR}$ anode [29], anodic oxidation with electrogenerated $\mathrm{H}_{2} \mathrm{O}_{2}$ or electro-Fenton or solar photoelectro-Fenton (always using a BDD anode) [44], and electrooxidation with a DSA [45] or BDD [46] anode. However, in the latter cases, mass transport of TBH to the anode surface was not optimized (a common electrochemical cell, with constant stirring by a rotary mixer, was used) and significant mineralization ( $80 \%)$ of the pesticide was attained only at very high current densities using the BDD anode; moreover, no identification of degradation intermediates was carried out and the influence of chlorinemediated oxidation on the TBH degradation was not considered $[45,46]$.

Because all the above, the aim of this work is to investigate the electrochemical degradation of TBH under enhanced mass transport conditions (using a filter-press flow cell with a BDD anode), assessing the effect of solution $\mathrm{pH}$, absence or presence of $\mathrm{Cl}^{-}$ions in solution, and current density on the herbicide degradation and resulting oxidation intermediates.

\section{Experimental}

\subsection{Chemicals}

All chemicals, including TBH $\left(500 \mathrm{~g} \mathrm{~L}^{-1}\right.$ commercial herbicide formulation from Atama Brasil containing 50\% of inert ingredients; or a.r., Sigma-Aldrich, 98,9\%), $\mathrm{Na}_{2} \mathrm{SO}_{4}$ (a.r., Qhemis), $\mathrm{NaCl}$ (a.r., Qhemis), $\mathrm{H}_{2} \mathrm{SO}_{4}$ (98\%, Mallinckrodt), $\mathrm{H}_{3} \mathrm{PO}_{4}$ (85\%, Mallinckrodt) $\mathrm{NaOH}$ (a.r., Qhemis), $\mathrm{H}_{2} \mathrm{O}_{2}$ (a.r., Synth, 30\%), $\mathrm{Na}_{2} \mathrm{~S}_{2} \mathrm{O}_{8}$ (a.r., Synth), $\mathrm{NaOCl}$ (a.r., Nalgon, 12\%), $\mathrm{Na}_{2} \mathrm{~S}_{2} \mathrm{O}_{3} .5 \mathrm{H}_{2} \mathrm{O}$ (a.r., Synth), acetonitrile (HPLC grade, JT Baker), methanol (HPLC grade, JT Baker), and carboxylic acids (a.r., Sigma-Aldrich), were used as received. All solutions were prepared using deionized water (Millipore Milli-Q, resistivity $\geq 18.2 \mathrm{M} \Omega \mathrm{cm}$ ).

\subsection{Electrochemical system}

Details concerning the experimental setup and the filter-press flow cell used to perform the electrolyses were reported elsewhere [22], along with data on the hydrodynamic conditions of the flow cell (solution linear velocity, mass transfer coefficient, and Reynolds number, for different flow rates). All electrolyses were carried out galvanostatically using an IMPAC (model 3645A) DC power supply. The solution $\mathrm{pH}$ and temperature were controlled using a Micronal (model B474) pH meter and a Nova Ética (model 512/2D) thermostatic bath, respectively.

A BDD electrode (from Condias GMbH Conductive Diamond Products, Germany) was used as anode throughout this work. The BDD film (boron content in the range of $2000-4500 \mathrm{ppm}$ ) on this electrode was deposited on both sides of a Nb plate by the chemical vapor deposition technique. In the flow cell, the total exposed geometric area of the BDD anode was $36.4 \mathrm{~cm}^{2}$; two AISI-304 stainless-steel plates of similar area were used as cathodes.

\subsection{Linear sweep voltammetry (LSV)}

LSV characterizations of naturally aerated aqueous $0.1 \mathrm{~mol} \mathrm{~L}^{-1}$ $\mathrm{Na}_{2} \mathrm{SO}_{4}$ solutions containing or not $100 \mathrm{mg} \mathrm{L}^{-1} \mathrm{TBH}$ (either from the analytical grade reagent or the commercial herbicide formulation) were performed to determine whether the inert ingredients present in the commercial formulation were electrooxidizable. For such, a conventional electrochemical cell was used, with a BDD electrode (fixed through a Viton O-ring to an acrylic holder that was directly immersed in the cell), a platinum foil, and an $\mathrm{Ag} / \mathrm{AgCl}\left(3 \mathrm{~mol} \mathrm{~L}^{-1} \mathrm{KCl}\right)$ electrode as working, counter and reference electrodes, respectively. All measurements were carried out at ambient temperature $\left(\sim 25^{\circ} \mathrm{C}\right)$, using a PGSTAT30 Autolab potentiostat/galvanostat controlled by the GPES software.

\subsection{Electrochemical degradation of $\mathrm{TBH}$ and ensuing analyses}

Before each electrolysis, the BDD anode was electrochemically pre-treated ( $50 \mathrm{mAcm}^{-2}$ for $10 \mathrm{~min}$ ) using a $0.10 \mathrm{~mol} \mathrm{~L}^{-1} \mathrm{Na}_{2} \mathrm{SO}_{4}$ solution; this assured that the anode surface was clean of any adsorbed organic material. The electrolyses were performed using $1.0 \mathrm{~L}$ of a $100 \mathrm{mg} \mathrm{L}^{-1} \mathrm{TBH}$ (from the commercial herbicide formulation) solution in aqueous $0.10 \mathrm{~mol} \mathrm{~L}^{-1} \quad \mathrm{Na}_{2} \mathrm{SO}_{4}$. The investigated variables and their values were: $i)$ solution $\mathrm{pH}(3$, 6,10 , or no specific control), ii) applied current density $(10,30$, $50 \mathrm{~mA} \mathrm{~cm}^{-2}$ ), and iii) absence or presence of $25 \mathrm{mmol} \mathrm{L}^{-1} \mathrm{Cl}^{-}$ions in the solution. No specific control of the $\mathrm{pH}$ means that during the electrolysis the solution $\mathrm{pH}$ was not adjusted to a fixed value (by addition of concentrated $\mathrm{H}_{2} \mathrm{SO}_{4}$ or $\mathrm{NaOH}$ ). Other parameters were kept fixed: temperature at $\sim 25^{\circ} \mathrm{C}$; volumetric flow rate at $6.5 \mathrm{~L} \mathrm{~min}^{-1}$ (flow velocity of $0.72 \mathrm{~m} \mathrm{~s}^{-1}$ ), like a previously optimized value [25].

The TBH concentration was monitored by high-performance liquid chromatography assays (HPLC system - Shimadzu LC20A pump with a SPD-20A UV-Vis detector set at $249 \mathrm{~nm}$ ) using a C18 reverse phase column (Kinetex: $150 \mathrm{~mm} \times 4.60 \mathrm{~mm}, 5 \mu \mathrm{m}, 100 \AA$ ) as the stationary phase and the isocratic elution mode with a water-acetonitrile mixture $(70: 30 \mathrm{~V} / \mathrm{V})$ as the mobile phase at a flow rate of $1 \mathrm{~mL} \mathrm{~min}{ }^{-1}$. For these assays, the electrolyzed solutions were sampled $(3 \mathrm{~mL})$ from time to time; as soon as obtained, a $25 \mu \mathrm{L}$ aliquot of a $100 \mathrm{~g} \mathrm{~L}^{-1} \mathrm{Na}_{2} \mathrm{~S}_{2} \mathrm{O}_{3} .5 \mathrm{H}_{2} \mathrm{O}$ solution was added to each sample to remove any oxidant species possibly present.

Chemical oxygen demand (COD) analyses and total organic carbon $(T O C)$ determinations were carried out as described elsewhere [22].

Initial oxidation intermediates of the electrochemical degradation of TBH were determined by LC-MS/MS. For that, $5 \mathrm{~mL}$ samples 


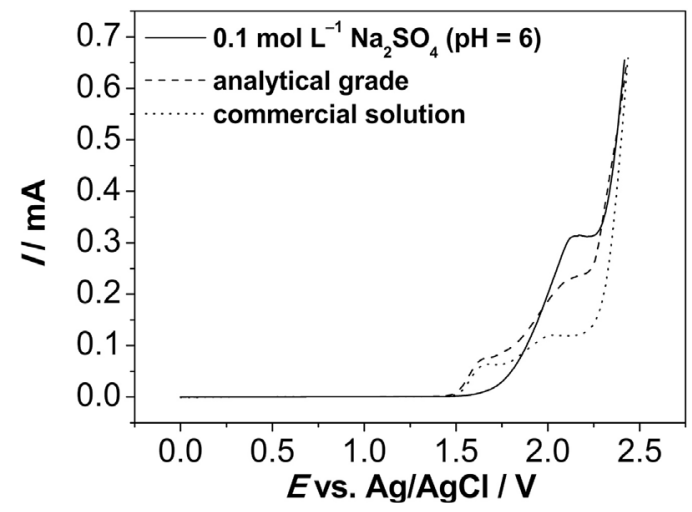

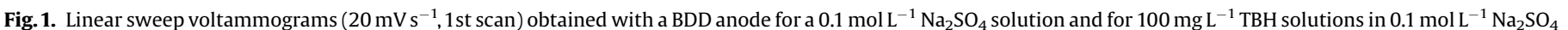
prepared using an analytical grade TBH reagent or a commercial herbicide TBH solution, as indicated in the figure.

of the electrolyzed solutions were first frozen and then dried for at least $24 \mathrm{~h}$ in a lyophilization system (Christ, Alpha 2-4 LD plus). Afterward, the dried solid was resuspended in $2 \mathrm{~mL}$ of methanol and filtered using a glass syringe with a $0.22 \mu \mathrm{m}$ PVDF cartridge. Then, these filtered solutions were analyzed by LC-MS/MS using a 1200 Agilent Technologies LC chromatographic system coupled to a DAD 1260 detector and an AB SCIEX 3200 QTRAP mass spectrometer (quadrupole linear ion trap), operating in the positive mode, with a TurbolonSpray ${ }^{\circledR}$ probe. The collision energies and mass/charge $(\mathrm{m} / \mathrm{z})$ ratios were investigated in the ranges of $15-45 \mathrm{eV}$ and $90-600$, respectively. These analyses were performed using a mixture of a $0.1 \%$ formic acid aqueous solution and acetonitrile $(75: 25, V / V)$ as the mobile phase, with injection volumes and analysis times of $20 \mu \mathrm{L}$ and $10 \mathrm{~min}$, respectively.

Terminal oxidation intermediates (short-chain carboxylic acids) of the electrochemical degradation of TBH were determined by HPLC, as described elsewhere [17].

\section{Results and discussion}

To start with, it was determined whether the inert ingredients contained in the commercial TBH herbicide formulation contributed any organic load to the TBH solution or were electrooxidizable on the BDD anode. Firstly, the COD and TOC concentrations of $100 \mathrm{mg} \mathrm{L}^{-1} \mathrm{TBH}$ solutions prepared using the analytical grade TBH reagent or the commercial $\mathrm{TBH}$ herbicide formulation were determined. As can be seen in Table SC- 1 in the supplementary content file, very similar (within experimental error) COD and TOC values were obtained. Hence, it could be concluded that the inert ingredients of the commercial herbicide formulation did not affect the organic load of the TBH solution, which, thus, was due only to TBH itself. Secondly, linear sweep voltammograms of those solutions were obtained. As can be apprehended from Fig. 1, no significant differences (except for the current intensity) were observed between the voltammetric profiles for the TBH solutions prepared from the analytical grade reagent or the commercial herbicide formulation; an oxidation peak around $1.6 \mathrm{~V}$ (vs. $\mathrm{Ag} / \mathrm{AgCl}$ $\left(3 \mathrm{~mol} \mathrm{~L}^{-1} \mathrm{KCl}\right.$ )) is clearly due to TBH and a second peak (starting at $\sim 1.75 \mathrm{~V}$ ) is associated to the BDD anode itself. As previously observed in our laboratory [47], the specific BDD anode used exhibits this characteristic peak, which can be attributed to $\mathrm{sp}^{2}$ carbon oxidation. Consequently, it could also be concluded that the inert ingredients present in the commercial TBH herbicide formulation were not electrooxidizable and thus did not significantly affect the electrochemical response of the BDD anode.

\subsection{Electrochemical degradation of TBH in the absence and presence of $\mathrm{Cl}^{-}$ions}

\subsubsection{Effect of solution $\mathrm{pH}$}

As can be inferred from Fig. 2a, the TBH degradation rate (at $j=30 \mathrm{~mA} \mathrm{~cm}^{-2}$ ) was not affected by the solution $\mathrm{pH}$ (in the range of 3-10) or the presence of $\mathrm{Cl}^{-}$ions in solution; the corresponding pseudo-first order kinetic constants, $k_{1 \text { st }}$, are listed in Table SC-2 in the supplementary content file. The degradation rate independence of $\mathrm{pH}$ is most probably due to TBH being always in its molecular form $\left(\mathrm{C}_{9} \mathrm{H}_{16} \mathrm{~N}_{4} \mathrm{OS}\right)$ in the investigated $\mathrm{pH}$ range; as reported by Weber [48], TBH displays basic properties and

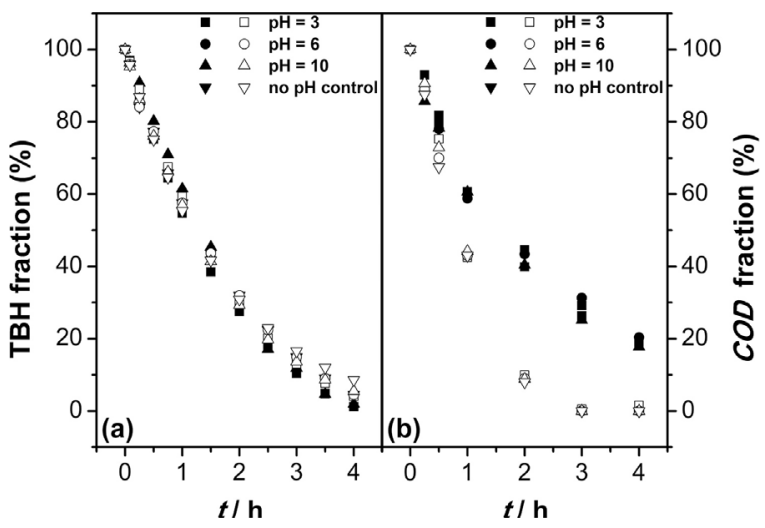

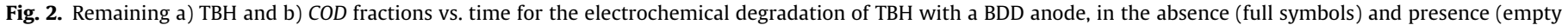

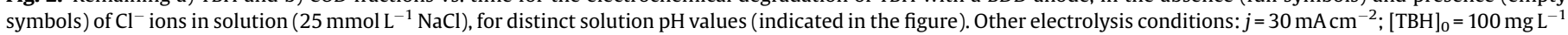
in $0.1 \mathrm{~mol} \mathrm{~L}^{-1} \mathrm{Na}_{2} \mathrm{SO}_{4} ; V=1.0 \mathrm{~L} ; q_{V}=6.5 \mathrm{~L} \mathrm{~min}^{-1} ; \theta \approx 25^{\circ} \mathrm{C}$. 


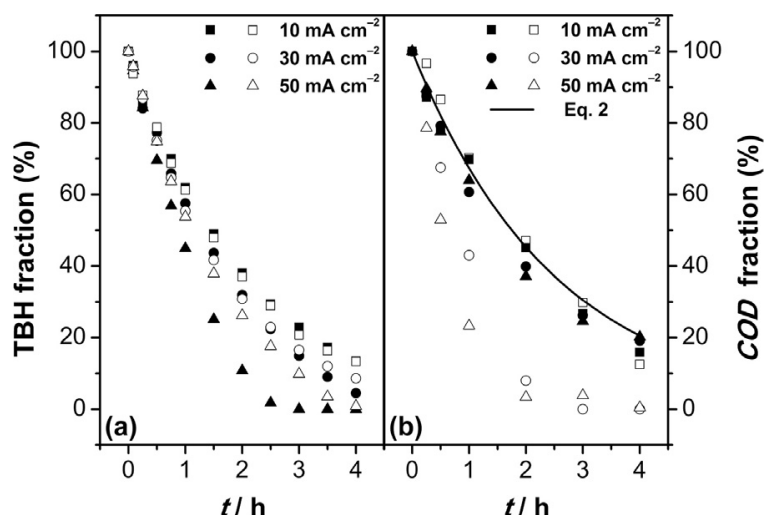

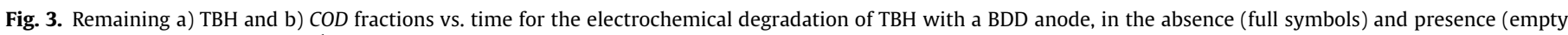

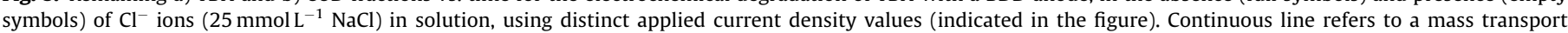

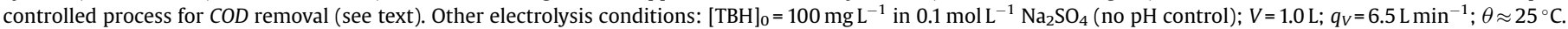

becomes significantly protonated only at $\mathrm{pH}<3$. On the other hand, the TBH resistance to oxidation by active chlorine species disagrees with what has been reported in the literature for several other organics, e.g. dyes $[7,47,49,50]$ and herbicides $[22,51,52]$. Hence, an additional experiment was carried out to confirm that resistance: sufficient $\mathrm{NaOCl}$ was added under stirring to $100 \mathrm{~mL}$ of a $100 \mathrm{mg} \mathrm{L}^{-1}$ TBH solution at $\mathrm{pH} 6$ to attain a final $\mathrm{HOCl}$ concentration of $200 \mathrm{mg} \mathrm{L}^{-1}$; then [TBH] was monitored for $1 \mathrm{~h}$. As can be seen in Fig. SC- 1 in the supplementary content file, the value of [TBH] does not change at all; thus, TBH is indeed resistant to oxidation by active chlorine. However, in principle, mediated oxidation processes in the solution bulk could also be promoted by other oxidants, such as $\mathrm{S}_{2} \mathrm{O}_{8}{ }^{2-}$ ions [32] and $\mathrm{H}_{2} \mathrm{O}_{2}$ [34], especially when the electrolysis is carried for a $\mathrm{SO}_{4}{ }^{2-}$ ion-containing solution using BDD anodes. Thus, other additional experiments were carried out to assess whether $\mathrm{S}_{2} \mathrm{O}_{8}{ }^{2-}$ ions and $\mathrm{H}_{2} \mathrm{O}_{2}$ were capable of oxidizing TBH. Again, as can be inferred from data in Fig. SC-1, there were no significant changes in the value of [TBH]. Hence, clearly no mediated oxidation of TBH takes place in the solution bulk during the electrolytic processes in the presence or absence of $\mathrm{Cl}^{-}$ions. Thus, the oxidation of TBH necessarily occurs in the region close to the BDD anode, either directly on the surface or by hydroxyl radicals within the reaction cage [53].

As for the COD removal - see Fig. 2b, despite no effect of solution $\mathrm{pH}$, significantly higher rates were attained in the presence of $\mathrm{Cl}^{-}$ions in solution (see the corresponding pseudofirst order kinetic constants in Table SC-2 in the supplementary content file). This result can be explained as possibly due to the susceptibility of degradation intermediates to oxidation by active chlorine species (probably by addition reactions [54]), leading to the formation of organochlorine compounds that cannot be oxidized by dichromate ions, thus leading to a false, exaggerated level of $C O D$ removal, as previously pointed out [49]. This view is corroborated by the fact that there is a remaining TBH fraction ( $>10 \%$ ) when all the $C O D$ is already removed, which is paradoxical - see data for $t=3 \mathrm{~h}$ in Fig. 2(b). According to Bonfatti et al. [55], when electrolyses are carried out in the presence of $\mathrm{Cl}^{-}$ions, adsorbed $\mathrm{Cl}^{\circ}$ and $\mathrm{ClO}^{\circ}$ radicals can also be produced on the surface of anodes by reaction with $\mathrm{HO}^{\bullet}$ radicals, contributing to $\mathrm{COD}$ removal.

Considering that the TBH and $C O D$ removal rates are insensitive to solution $\mathrm{pH}$, all remaining experiments were carried out without any $\mathrm{pH}$ control; this is a welcome advantage of the electrochemical degradation process comparatively to Fenton processes, in which the solution $\mathrm{pH}$ must be inescapably kept within a given acidic range.

\subsubsection{Effect of applied current density}

As can be inferred from Fig. 3a, in the absence of $\mathrm{Cl}^{-}$ions in solution the TBH removal rate increases with $j$ (see $k_{1 \text { st }}$ values in Table SC-2 in the supplementary content file). Considering that the system is controlled by mass transfer, such increase in the removal rate must be due to additional turbulence promoted by increased gas evolution, resulting in a higher mass transport coefficient [56]. For $j=50 \mathrm{~mA} \mathrm{~cm}^{-2}$, TBH is completely removed within only $3 \mathrm{~h}$ of electrolysis; with a common electrochemical cell, such complete removal could not be attained even at $j=200 \mathrm{~mA} \mathrm{~cm}^{-2}$ (see [46]). This significantly improved performance is due to the enhanced mass transport conditions assured using a flow cell.

The COD removal rate (Fig. 3(b)), contrary to that of [TBH], is independent of $j$ (see $k_{1 \text { st }}$ values in Table SC- 2 in the supplementary content file), a behavior typical of mass transport controlled processes, in which the limiting step is the diffusion of the organic molecule to the anode surface. Under these conditions, the main hydrodynamic parameter is the mass transfer coefficient $\left(k_{m}\right)$, whose value for the flow reactor that was used is $2.96 \times 10^{-5} \mathrm{~m} \mathrm{~s}^{-1}$ (obtained according to Cañizares et al. [57] - see supplementary content file of Ref. [22]). As explained and discussed elsewhere [22], considering this value of $k_{m}$ it is possible to calculate [58] the initial limiting current density $\left(j_{\lim }^{0}\right.$, see Eq. (1)) for the removal of $C O D$ and then the theoretical exponential decay of the COD fraction $-x_{C O D}$ (see Eq. (2)) at different times, as described by Kapalka et al. [34].

$j_{\lim }^{0}=4 F k_{m} C O D_{0}=6.8 \mathrm{~mA} \mathrm{~cm}^{-2}$

$x_{C O D}=\frac{C O D_{t}}{C O D_{0}}=\exp \left(-\frac{A k_{m} t}{V}\right)$

where 4 is the number of electrons involved in the removal of $C O D$, $F$ the Faraday constant, $A$ the geometric area of the BDD anode, $V$ the electrolyzed solution volume, $t$ the electrolysis time, and $C O D_{0}$ and $C O D_{t}$ are the $C O D$ values at $t=0\left(\sim 190 \mathrm{mg} \mathrm{L}^{-1}\right)$ and after a given time $t$. In fact, equation 2 embodies the highest possible rate of $C O D$ removal for processes controlled by mass transfer. As can be observed in Fig. 3b (solid symbols), the experimental points are in good agreement with the theoretical decay line resulting from this equation; as the system is controlled by mass transport, further increases of the applied current density do not result in higher $C O D$ removal rates. At $50 \mathrm{~mA} \mathrm{~cm}^{-2}$, the small improvement of the $C O D$ removal rates could also be due to additional turbulence promoted by gas evolution, resulting in a higher mass transport coefficient, as discussed above. 
When the TBH removal rates in the presence of $\mathrm{Cl}^{-}$ions in solution are compared to those in their absence, no significant improvement is attained by increasing $j$ from 10 to $30 \mathrm{mAcm}^{-2}$. Interestingly, at $j=50 \mathrm{mAcm}^{-2}$ the presence of $\mathrm{Cl}^{-}$ions led to a decrease in the TBH removal rate, which might be due to consumption of $\mathrm{HO}^{\bullet}$ radicals in the oxidation of active chlorine species resulting in the $\mathrm{ClO}_{2}{ }^{-}, \mathrm{ClO}_{3}{ }^{-}$or $\mathrm{ClO}_{4}{ }^{-}$species, as described in the literature [59-61]. This possible behavior was confirmed by the quantification of electrogenerated active chlorine (as $\mathrm{OCl}^{-}$) during the electrolysis of a $0.1 \mathrm{~mol} \mathrm{~L}^{-1} \mathrm{Na}_{2} \mathrm{SO}_{4}$ solution in the presence of $25 \mathrm{mmol} \mathrm{L}^{-1} \mathrm{NaCl}$ at $\mathrm{pH} \mathrm{6}$; additional experimental details, as well as the calibration curve for the $\mathrm{OCl}^{-}$quantification, are available in the supplementary content file. As expected, $\left[\mathrm{OCl}^{-}\right]$ increased with $j$ - see Fig. SC-2(b) in the supplementary content file; however, for $j=50 \mathrm{~mA} \mathrm{~cm}^{-2}\left[\mathrm{OCl}^{-}\right]$abruptly decreases after $2 \mathrm{~h}$ of electrolysis, probably due to the oxidation of active chlorine species by hydroxyl radicals to one of the higher oxidation states of chlorine, i.e. $\mathrm{ClO}_{2}{ }^{-}, \mathrm{ClO}_{3}{ }^{-}$or $\mathrm{ClO}_{4}{ }^{-}$, which are inefficient oxidizers of organic matter [61]. This characteristic combined with a local decrease of $\left[\mathrm{HO}^{\bullet}\right]$ on the BDD surface leads to lower TBH removal rates comparatively to the conditions in the absence of $\mathrm{Cl}^{-}$ions. In the case of $C O D$, the presence of $\mathrm{Cl}^{-}$ions in solution led to significantly greater $C O D$ removal rates as $j$ was increased to 30 and $50 \mathrm{~mA} \mathrm{~cm}^{-2}$ (see $k_{1 \mathrm{st}}$ values in Table SC-2 in the supplementary content file), as previously observed for the electrochemical degradation of the herbicide picloram also using a BDD anode [22]. As discussed above, since the $C O D$ removal levels are higher than the TBH removal levels, such behavior might be due to the production of organochlorines by the chlorine-mediated oxidation of TBH degradation intermediates in the solution bulk. For $j=10 \mathrm{~mA} \mathrm{~cm}^{-2}$, the experimental and theoretical values of $x_{C O D}$ are in very good agreement; hence, it can be concluded that in this case the chlorine-mediated oxidation of TBH degradation intermediates is insignificant, most probably due to the lower concentration of active chlorine species. In fact, according to Anglada et al. [61], when the value of $j$ is near the limiting one, which is the case for $j=10 \mathrm{~mA} \mathrm{~cm}^{-2}$, the degradation of the organic load occurs mainly through oxidation by hydroxyl radicals.

As can be inferred from Fig. 4, in the absence of $\mathrm{Cl}^{-}$ions in solution, higher TOC removal rates were obtained for $j=30$ and $50 \mathrm{~mA} \mathrm{~cm}^{-2}$ (see $k_{1 \mathrm{st}}$ values in Table SC-4 in the supplementary content file); those rates are in good agreement with the theoretical one for mass transport controlled processes (obtained by substitution of the COD values by TOC ones in Eq. (2)). High TOC removals of about $70 \%$ or $90 \%$ were attained after 3 or $6 \mathrm{~h}$ of electrolysis; this performance is significantly better than that attained using a common electrochemical cell ( $T O C$ removal of only about $20 \%$ after 3 of electrolysis at $j=50 \mathrm{~mA} \mathrm{~cm}^{-2}$-see [46]), which attests once again the importance of enhanced mass transport conditions.

When the electrolyses are carried out in the presence of $\mathrm{Cl}^{-}$ions in solution, no clear tendency is observed for the TOC removal compared to that in their absence, since a slight decrease or increase of the TOC removal rate is achieved at $j=30$ or $50 \mathrm{~mA}$ $\mathrm{cm}^{-2}$, respectively. Previously, Murugananthan et al. [62] reported a decrease of the TOC removal rate when $0.1 \mathrm{~mol} \mathrm{~L}^{-1} \mathrm{NaCl}$ was used as the supporting electrolyte solution for the electrochemical degradation of bisphenol A (initial concentration of $20 \mathrm{mg} \mathrm{L}^{-1}$ ) with a BDD anode, comparatively to experiments performed using $\mathrm{Na}_{2} \mathrm{SO}_{4}$ and $\mathrm{NaNO}_{3}$ as supporting electrolyte. The formation of organochlorinated intermediates was pointed out as the main reason for the observed low rates of TOC removal. More recently, Pereira et al. [22] reported no influence of chlorine-mediated oxidation in the TOC removal rate during the electrochemical degradation of the herbicide picloram using a BDD anode. However, under the same conditions, a significant influence was observed when a $\beta-\mathrm{PbO}_{2}$ anode was used, despite lower TOC removal rates; this was explained as possibly due to different oxidation mechanisms associated to each anode. To have a better view of the TBH oxidation processes in the absence or presence of $\mathrm{Cl}^{-}$ions in solution, the respective $C O D$ and TOC data for $6 \mathrm{~h}$ electrolyses were plotted together - see Fig. SC-3 in the supplementary content file. In the absence of $\mathrm{Cl}^{-}$ions in solution, the $C O D$ and $T O C$ removal rates are very close, except for $j=10 \mathrm{~mA} \mathrm{~cm}^{-2}$ (see Fig. SC-3a or compare the respective $k_{1 \mathrm{st}}$ values in Tables SC-3 and SC-4 in the supplementary content file); this implies that at the higher $j$ values there is no significant accumulation of degradation intermediates in the electrolyzing solution. However, in the presence of $\mathrm{Cl}^{-}$ions in solution, the $C O D$ removal rates are significantly higher (see Fig. SC-3b or compare the respective $k_{1 \text { st }}$ values in Tables SC-3 and SC-4 in the supplementary content file). As discussed above, one possible explanation for these results is the accumulation in solution of highly recalcitrant organochlorinated intermediates, which are not susceptible to oxidation by dichromate; therefore, the measured $C O D$ values do not account for the real concentration of organic matter in the electrolyzed solution, as pointed out by Baker et al. [63]. Similar results concerning the effect of chlorine-mediated oxidation on the measured $C O D$ values were obtained for other synthetic organic compounds, e.g. a pesticide [22] or some dyes [49].

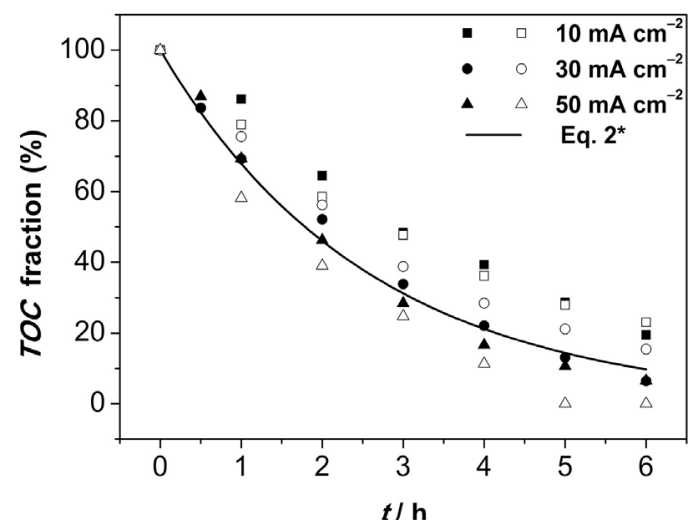

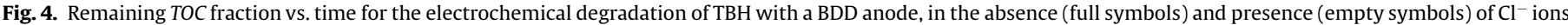

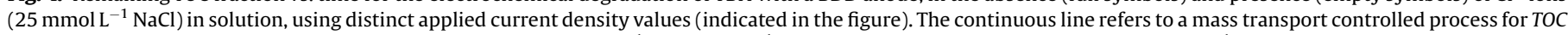
removal (see text). Other electrolysis conditions: $[\mathrm{TBH}]_{0}=100 \mathrm{mg} \mathrm{L}^{-1}$ in $0.1 \mathrm{~mol} \mathrm{~L}^{-1} \mathrm{Na}_{2} \mathrm{SO}_{4}\left(\right.$ no pH control); $V=1.0 \mathrm{~L} ; q_{V}=6.5 \mathrm{~L}$ min ${ }^{-1} ; \theta \approx 25^{\circ} \mathrm{C}$. 
3.1.3. Detailed account on current efficiency and energy consumption

Values of the general current efficiency (GCE) can be determined as a function of the $C O D$ removal (in the absence of $\mathrm{Cl}^{-}$ions in solution, for the reasons discussed above), for the distinct values of $j$, using the following equation [32]:

$G C E=\frac{\Delta C O D_{t} F V}{8 \times 10^{3} I t} \times 100$

where $\triangle C O D_{t}$ is the measured $C O D$ removal $\left(\mathrm{mg} \mathrm{L}^{-1}\right)$ after a given treatment time $t(\mathrm{~s}), F$ is the Faraday constant $\left(96485 \mathrm{C} \mathrm{mol}^{-1}\right), V$ the solution volume $(\mathrm{L}), 8 \times 10^{3}$ (in $\mathrm{mg} \mathrm{mol}^{-1}$ ) a conversion factor, and $I$ the applied current $(\mathrm{A})$. Due to mass transfer limitations, it can be expected that the value of GCE will increase as $j$ decreases (approaching $j_{\text {lim }}^{0}$ ) at a fixed $C O D_{0}$ value and as $C O D_{0}$ increases at a fixed $j$ value. Considering that the TOC removal was determined for up to $6 \mathrm{~h}$ of electrolysis (Fig. 4), the data for the decay of the $C O D$ fraction (Fig. 3) can be extrapolated for this same time of electrolysis, when $x_{C O D}$ can be considered to become zero (attainment of total $C O D$ removal). Thus, after $6 \mathrm{~h}$ of electrolysis, the values of $G C E$ (for $j=50,30$, and $10 \mathrm{~mA} \mathrm{~cm}^{-2}$ ) can be estimated to be approximately $6 \%, 10 \%$, and $29 \%$, respectively. These values are low because $C O D_{0}$ is quite low $\left(\approx 190 \mathrm{mg} \mathrm{L}^{-1}\right)$ and the values of $j$ are greater than that of $j_{\lim }^{0}\left(=6.8 \mathrm{~mA} \mathrm{~cm}^{-2}\right)$. However, these values of GCE stand out when compared to those estimated for different data in the literature (when a flow reactor and a BDD anode were also used). For instance, for the electrooxidation of: a) methylene blue $\left(C O D_{0}=168 \mathrm{mg} \mathrm{L}^{-1}\right)$ at $j=20 \mathrm{mAcm}^{-2}\left(x_{C O D}=0\right), G C E \approx 7 \%$ [64]; b) 2-propanol $\left(C O D_{0}=105 \mathrm{mg} \mathrm{L}^{-1}\right)$ at $j=30 \mathrm{~mA} \mathrm{~cm}^{-2}\left(x_{C O D}=\right.$ $0.1), G C E \approx 3 \%$ [65]. The improved values of GCE here reported are certainly due to the attainment of better hydrodynamic conditions in the filter-press reactor that was used. In fact, when a similar filter-press reactor was used in the electrooxidation of a bisphenol A $\left(C O D_{0}=330 \mathrm{mg} \mathrm{L}^{-1}\right)$ at $j=6.5 \mathrm{mAcm}^{-2}\left(x_{C O D}=0.1\right)$ [25], the obtained value of GCE was about $56 \%$, which corresponds to a very good performance. Nevertheless, even the higher values of GCE reported in this work $(\leq 29 \%)$ imply that a significant current inefficiency necessarily occurs due to mass transfer limitations imposed by the solution's low organic load and this inefficiency is exacerbated as $j$ becomes increasingly greater than $j_{\text {lim. }}^{0}$. In other words, the used electric charge becomes increasingly (and significantly) larger than that for an ideal electrooxidation process (when GCE $=100 \%$ ). Clearly, electrooxidation of organic contaminants at low initial concentrations necessarily have to be carried out at a current density as close as possible to $j_{\text {lim }}^{0}$ and under truly enhanced mass transfer conditions, i.e. using better, ingeniously designed flow reactors; otherwise, the current efficiency of the electrooxidation process will be low.

Next, values of the mineralization current efficiency (MCE) and energy consumption per unit TOC mass removed $\left(E C_{T O C}\right)$ were determined as a function of TOC removal in the absence and presence of $\mathrm{Cl}^{-}$ions in solution, for the distinct values of $j$, using the following equations [67]:

$M C E=\frac{\Delta T O C_{t} n F V}{4.32 \times 10^{7} \mathrm{mIt}} \times 100$

$E C_{T O C}=\frac{E I t}{\Delta T O C V}$

where $\triangle T O C_{t}$ is the measured TOC removal $\left(\mathrm{mg} \mathrm{L}^{-1}\right)$ after a given treatment time $t(\mathrm{~s}), n$ the number of exchanged electrons (76) obtained considering that the applied electric charge was consumed solely by the mineralization of $\mathrm{TBH}$ to $\mathrm{CO}_{2}$, with concomitant formation of $\mathrm{NO}_{3}{ }^{-}, \mathrm{SO}_{4}{ }^{2-}$ and $\mathrm{H}^{+}$ions (see refs. $[29,44]), F$ is the Faraday constant $\left(96485 \mathrm{C} \mathrm{mol}^{-1}\right), V$ the solution volume $(\mathrm{L}), 4.32 \times 10^{7}$ an amalgamated conversion factor ( $3600 \mathrm{~s}$ $\left.\mathrm{h}^{-1} \times 12000 \mathrm{mg} \mathrm{mol}^{-1}\right), m$ the number of carbon atoms (9) in the TBH molecule, $I$ the applied current (A), and $E$ the cell potential (V). As can be seen in Fig. 5a, the MCE vs. TOC removal profiles are like those characteristic of electrochemical methods [17], i.e. after initial high values, MCE gradually decreases as the removed TOC fraction increases, i.e. as the organic load is mineralized. As expected, significantly higher MCE values are attained for $j=10$ $\mathrm{mA} \mathrm{cm}{ }^{-2}$, in the absence and presence of $\mathrm{Cl}^{-}$ions: about $15 \%$, after $6 \mathrm{~h}$ of electrolysis. As could be expected, the MCE value is lower than that of the GCE; indeed, mineralization of the organics is harder to attain than the removal of its $C O D$ [66]. Furthermore, when the $E C_{T O C}$ vs. TOC removal profiles are analyzed, the results for $j=10 \mathrm{~mA} \mathrm{~cm}^{-2}$ stand out again: quite low values are obtained, either in the absence or presence of $\mathrm{Cl}^{-}$ions in solution. After 6 hours of electrolysis, a high TOC removal level (80\%) is attainable with an $E C_{\text {TOC }}$ value of $\approx 0.2 \mathrm{~kW} \mathrm{~h} \mathrm{~g}{ }^{-1}$, with no need to add $\mathrm{Cl}^{-}$ions to the electrolyzed solution, thus avoiding the risk of formation of organochlorines. As expected, the $E C_{T O C}$ values are higher for $j=30$ and $50 \mathrm{~mA} \mathrm{~cm}^{-2}$, increasing more significantly in the final stages of the mineralization process as the organic load in solution becomes drastically decreased.

Despite the relatively high number of papers reporting on the degradation of TBH $[7,29,38-46]$, a comparison of their main

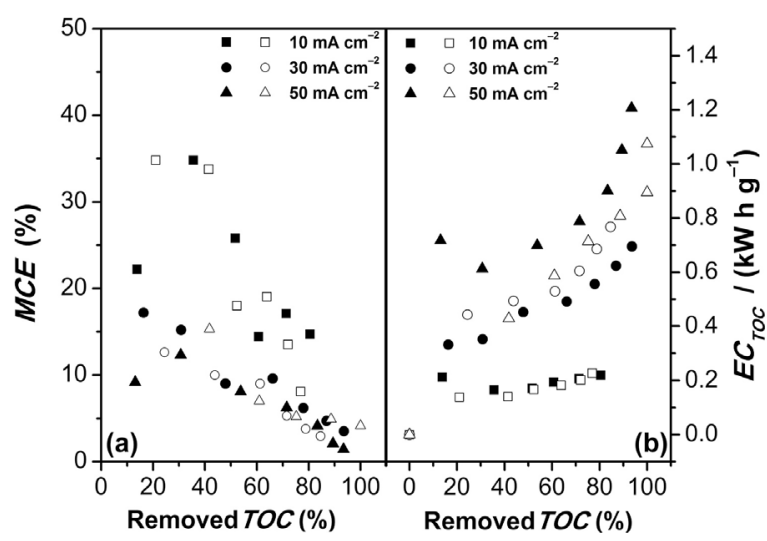

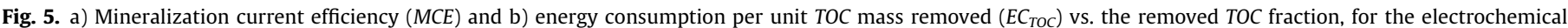

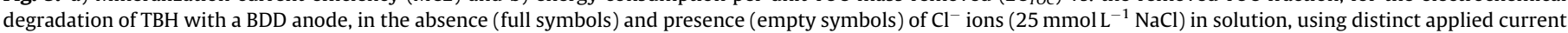

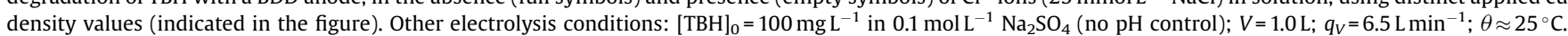


results with the ones here reported is difficult because distinct experimental conditions and system configurations were used; nevertheless, approximate comparisons can be done with the two cases that only used electrochemical technology. In the first one, Alves et al. [45] investigated the electrooxidation of TBH in a conventional electrochemical cell with a $\mathrm{DSA}^{\mathbb{R}}$ anode, with constant stirring by a rotary mixer $\left(0.45 \mathrm{~L}\right.$ of a $100 \mathrm{mg} \mathrm{L}^{-1} \mathrm{TBH}$ prepared from a commercial formulation, in the absence of $\mathrm{Cl}^{-}$ions and using $200 \mathrm{~mA} \mathrm{~cm}^{-2}$ ). After $3 \mathrm{~h}$ of electrolysis, TBH and TOC removal values of only $20 \%$ and $13 \%$ were attained, respectively, with $E C_{T O C}$ being about $23 \mathrm{~kW} \mathrm{~h} \mathrm{~g}^{-1}$. The value of $E C_{T O C}$ decreased to about $11 \mathrm{~kW} \mathrm{~h} \mathrm{~g}^{-1}$ when $j=75 \mathrm{~mA} \mathrm{~cm}^{-2}$ was used; however, then the attained TOC removal was only $6 \%$. As discussed above, using the filter-press reactor a comparatively low $E C_{T O C}$ value of only $\sim 0.2 \mathrm{~kW} \mathrm{~h} \mathrm{~g}^{-1}$ was attained for $j=10 \mathrm{mAcm}^{-2}$, but with a TOC removal of $80 \%$. In a second work, using the same experimental conditions and cell setup but with BDD anodes of distinct boron doping levels (5000 and $30000 \mathrm{ppm}$ ), TOC removals close to $80 \%$ were reported by Alves et al. [46] for $j=200 \mathrm{~mA}^{-2}$, but with associated values of $E C_{T O C}$ of about $4 \mathrm{~kW} \mathrm{~h} \mathrm{~g}^{-1}$ (5000 ppm BDD) and $3 \mathrm{~kW} \mathrm{~h} \mathrm{~g}^{-1}$ (30000 ppm BDD). These $E C_{\text {TOC }}$ values are about 20 and 15 times greater, respectively, than the one here reported. For $j=10 \mathrm{~mA} \mathrm{~cm}^{-2}$, Alves et al. [46] reported values of about $\sim 1 \mathrm{~kW}$ $\mathrm{hg}^{-1}$ (5000 ppm BDD) and $\sim 0.7 \mathrm{kWh} \mathrm{h}^{-1}$ (30000 ppm BDD); however, then TOC removals of only $10 \%$ (5000 ppm) or $5 \%$ $(30000 \mathrm{ppm})$ were attained after $3 \mathrm{~h}$ of electrolysis. Hence, from the above comparisons, enhanced mass transport conditions clearly do lead to higher mineralization levels with significantly lower energy expenses; similar improved results were previously reported for the electrochemical degradation of bisphenol A [25].

\subsection{Oxidation intermediates in the absence and presence of $\mathrm{Cl}^{-}$ions}

\subsubsection{Initial oxidation intermediates}

The detected main initial oxidation intermediates, as well as their corresponding retention times, main fragment ions, and proposed chemical structure, are listed in Tables 1 and 2, for TBH electrolyses in the absence and presence of $\mathrm{Cl}^{-}$ions in solution, respectively; proposed fragmentation pathways can be seen in Figs. SC -4 to SC-11 in the supplementary content file.

In the absence of $\mathrm{Cl}^{-}$ions in solution, as can be inferred from the proposed chemical structures shown in Table 1, initial oxidation intermediates resulted from hydroxylation reactions in the TBH molecule's central and terminal methyl groups of urea (see compounds 1 and 3, respectively), as well as on the methyl groups of the tert-butyl substituent (see compound 2). These oxidation intermediates were also detected by Silva et al. [42], who employed a photo-Fenton method, whereas only compounds 2 and 3 were detected by Montes et al. [29], who employed a hybrid electrochemical $\left(D^{\circ} A^{\mathbb{R}}\right.$ ) and photochemical (UVC radiation) method in the presence of $\mathrm{Cl}^{-}$ions. When advanced oxidation processes are used, typically all detected initial intermediates result from hydroxylation reactions (with increase of molar mass), followed by further oxidation leading to carbonyl groups that are then eliminated (with decrease of molar mass). Such process was confirmed by the detection of compounds $\mathbf{4}$ and $\mathbf{5}$; it should be noted that Montes et al. [29] and Silva et al. [42] also detected the latter compound. Hence, it can be expected that the initial oxidation pathway associated to the electrochemical degradation of TBH using a BDD anode is like those previously reported for coupled processes involving photochemistry [29,42].

Table 1

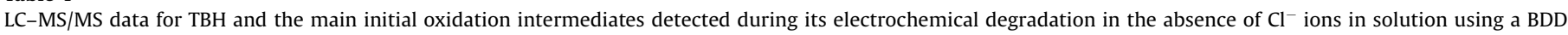
anode. $^{\mathrm{a}}$

\begin{tabular}{|c|c|c|c|c|c|}
\hline & $\begin{array}{l}\text { Molecular mass } \\
\text { (Da) }\end{array}$ & $\begin{array}{l}\text { Retention time } \\
(\mathrm{min})\end{array}$ & Molecular ion $[\mathrm{M}+\mathrm{H}]^{+}-m / z$ & Main fragment ions $-m / z$ & Proposed chemical structure \\
\hline TBH & 228 & 6.06 & 229 & $172,157,116$ & o \\
\hline
\end{tabular}

(1)

(2)

(5)

214
4.41
215
214, 188, 156

188, 156, 146, 132

172, 215

116, 172, 215

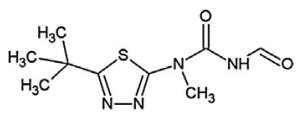<smiles>CNC(=O)N(CO)c1nnc(C(C)(C)C)s1</smiles><smiles>CNC(=O)N(C)c1nnc(C(C)(C)CO)s1</smiles><smiles>CN(C(=O)NCO)c1nnc(C(C)(C)C)s1</smiles>

$102,116,158,184$

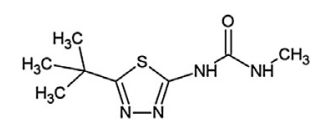

\footnotetext{
a Electrolysis conditions: $j=30 \mathrm{mAcm}^{-2} ;[\mathrm{TBH}]_{0}=100 \mathrm{mg} \mathrm{L}^{-1}$ in $0.1 \mathrm{~mol} \mathrm{~L}^{-1} \mathrm{Na}_{2} \mathrm{SO}_{4}$ (no pH control); $V=1.0 \mathrm{~L} ; q_{V}=6.5 \mathrm{Lmin}{ }^{-1} ; \theta \approx 25^{\circ} \mathrm{C}$.
} 
Table 2

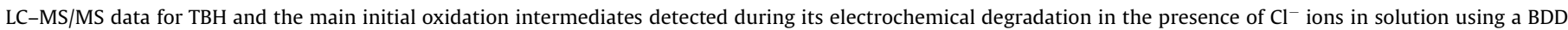
anode. $^{\mathrm{a}}$

\begin{tabular}{|c|c|c|c|c|c|}
\hline & $\begin{array}{l}\text { Molecular mass } \\
\text { (Da) }\end{array}$ & $\begin{array}{l}\text { Retention time } \\
\text { (min) }\end{array}$ & Molecular ion $[\mathrm{M}+\mathrm{H}]^{+}-m / z$ & Main fragment ions $-m / z$ & Proposed chemical structure \\
\hline TBH & 228 & 6.06 & 229 & $172,157,116$ & \\
\hline (5) & 214 & 4.38 & 215 & 158 & \\
\hline (6) & 262 & 8.36 & 263 & $206,157,142$ & \\
\hline (7) & 205 & 4.39 & 206 & $142,157,170$ & \\
\hline (8) & 171 & 2.81 & 172 & 116,89 & 4 \\
\hline
\end{tabular}

${ }^{a}$ Electrolysis conditions: $j=30 \mathrm{mAcm}^{-2} ;[\mathrm{TBH}]_{0}=100 \mathrm{mg} \mathrm{L}^{-1}$ in $0.1 \mathrm{~mol} \mathrm{~L}^{-1} \mathrm{Na}_{2} \mathrm{SO}_{4}+25 \mathrm{mmol} \mathrm{L}^{-1} \mathrm{NaCl}(\mathrm{no} \mathrm{pH} \mathrm{control}) ; V=1.0 \mathrm{~L} ; q_{V}=6.5 \mathrm{Lmin}{ }^{-1} ; \theta \approx 25{ }^{\circ} \mathrm{C}$.

When the electrolyses were carried out in the presence of $\mathrm{Cl}^{-}$ ions in solution, of the above-mentioned intermediates, only compound 5 was observed - see Table 2. In addition, two organochlorines were detected (see compound $\mathbf{6}$, also detected by Montes el al. [29], and compound 7); the possible occurrence of organochlorinated intermediates, which could result from the attack by $\mathrm{Cl}^{\circ}$ species on the surface of the BDD anode or by electrogenerated active chlorine species, was inferred above within the discussion of the $C O D$ removal data. Considering that the occurrence of organochlorines during electrolyses in the presence of $\mathrm{Cl}^{-}$ions is now confirmed, it can be concluded that the COD removal results obtained under these conditions are indeed not trustworthy. Furthermore, although no initial oxidation intermediate resulting from the opening of the TBH molecule's thiadiazole ring was detected, considering that almost total TOC removal was attained, such intermediates are certainly part of the TBH degradation pathway. Additionally, it should be noted that the detection of only a small number of initial intermediates could be due to the $j$ value used $\left(30 \mathrm{~mA} \mathrm{~cm}^{-2}\right.$ ), which is significantly higher than the limiting value, thus favoring the direct conversion of the organic compound (TBH) to $\mathrm{CO}_{2}$ instead of to intermediate compounds, as already discussed above and by Kapalka et al. [34], or reported e.g. by Coledam et al. [17]. This is characteristic of BDD anodes; in fact, preliminary results for the electrochemical degradation of TBH using a $\beta-\mathrm{PbO}_{2}$ anode show a significantly larger number of detected initial intermediates.

3.2.2. Terminal oxidation intermediates: short-chain carboxylic acids

First, considering the TBH molecular structure - see Table 1, it is reasonable to expect the detection only of straight-chain carboxylic acids with at most 3 carbon atoms, which was the case (see Fig. 6). In the absence of $\mathrm{Cl}^{-}$ions in solution, five acids were identified (see Fig. 6a), with only one (formic acid) being still detected by the end of the electrolysis, but at a low concentration.
It should be noted that a dicarboxylic acid (malonic acid) was identified, following the removal of its mother molecule, propanoic acid.

In the presence of $\mathrm{Cl}^{-}$ions in solution, five acids (including chloroacetic acid) were also identified (see Fig. 6b) and two of them (acetic and tartronic acid) were still detected by the end of the electrolysis; the latter, a highly oxidized acid, was accumulating. It should be noted that chloroacetic acid $-\mathrm{ClCH}_{2} \mathrm{COOH}-$ is a homologue of glycolic acid $-\mathrm{HOCH}_{2} \mathrm{COOH}$, which was detected when the electrolysis was carried out in the absence of $\mathrm{Cl}^{-}$ions in solution - see above. Montes el al. [29], also for the electrochemical degradation of TBH in the presence of $\mathrm{Cl}^{-}$ions $\left(34 \mathrm{mmol} \mathrm{L}^{-1}\right)$ using a BDD anode at $j=20 \mathrm{mAcm}^{-2}$ for $6 \mathrm{~h}$, reported the detection of about the same carboxylic acids (plus dichloroacetic acid, but no formic acid); however, then all the acids (except malonic acid) were accumulating during the electrolysis, which could be due to the lower value of $j$ employed.

Here it should be noted that, although organochlorinated intermediates were detected during the electrochemical degradation of TBH in the presence of $\mathrm{Cl}^{-}$ions in solution, such intermediates were no longer detected at the end of the $8 \mathrm{~h}$ electrolysis. Finally, it should also be noted that, surprisingly, no signals of the recalcitrant oxalic and oxamic acids [67] were detected during the experiments; anyway, these acids were also not detected by Montes et al. [29]. On the other hand, when the TBH degradation was carried out with a BDD anode in the presence of electrogenerated $\mathrm{H}_{2} \mathrm{O}_{2}$ [44], no short-linear carboxylic acids were detected at all, despite attaining TBH and TOC removals of about $74 \%$ and $36 \%$, respectively, after $6 \mathrm{~h}$ of treatment.

\section{Conclusions}

The use of enhanced mass transport conditions (filter-press flow cell) led to significantly improved performances in the 

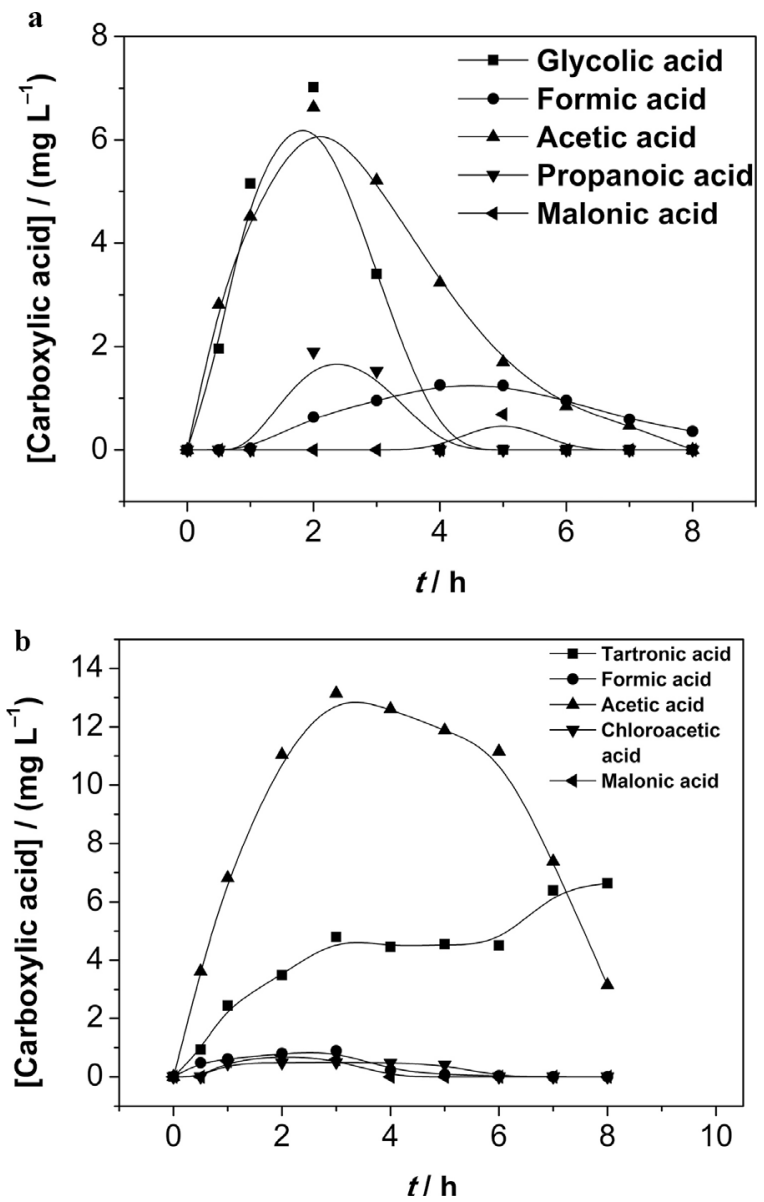

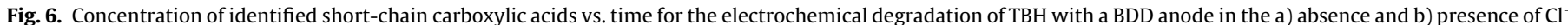

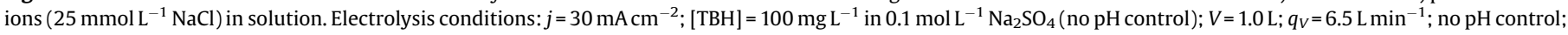
$\theta \approx 25^{\circ} \mathrm{C}$.

electrochemical degradation of $\mathrm{TBH}$, comparatively to what was previously attained using a common electrochemical cell [46]. The solution $\mathrm{pH}$ or the presence of $\mathrm{Cl}^{-}$ions in solution did not affect the degradation rate of $\mathrm{TBH}$ (the resistance to oxidation by active chlorine species was further confirmed by exposing it to $\mathrm{HOCl}$ ). The COD removal rate, despite being independent of $\mathrm{pH}$, was significantly faster in the presence of $\mathrm{Cl}^{-}$ions in solution, most probably due to false (exaggerated) $C O D$ removal values caused by organochlorinated intermediate compounds.

In the absence of $\mathrm{Cl}^{-}$ions in solution, the $C O D$ removal rate was not affected by $j$, which is typical of mass transport controlled processes; however, significantly increased removal rates were attained in the presence of $\mathrm{Cl}^{-}$ions in solution, most probably because of increased formation of organochlorine compounds that lead to false (exaggerated) $C O D$ removal values.

As expected, higher values of the general and mineralization current efficiencies were attained at the lower current density used $\left(10 \mathrm{~mA} \mathrm{~cm}^{-2}\right)$, with lower energy consumptions per unit TOC mass removed $\left(E C_{T O C}\right)$; in fact, in the absence of $\mathrm{Cl}^{-}$ions in solution, complete removal of TBH and COD as well as $80 \%$ removal of TOC were attained with a comparatively low value of $E C_{T O C}(0.2 \mathrm{~kW} \mathrm{~h}$ $\mathrm{g}^{-1}$ ), which is less than one tenth of the ones for electrolyses using a conventional electrochemical cell. Clearly, enhanced mass transport conditions do lead to higher mineralization levels with significantly lower energy expenses. Nevertheless, the corresponding general and mineralization current efficiencies were $29 \%$ and $15 \%$, respectively, evidencing that at low organics concentrations, electrooxidation must necessarily be carried out at a current density as close as possible to $j_{\text {lim }}^{0}$ and under truly enhanced mass transfer conditions; otherwise, alternative approaches need to be explored.

From the identified intermediates, the initial oxidation pathway associated to the electrochemical degradation of TBH using a BDD anode is expected to be like those of coupled processes involving photochemistry. Several terminal oxidation intermediates (highly oxidized short-chain carboxylic acids) were detected and quantified, being mostly removed by the end of the electrolyses (except for tartronic acid that accumulated in the presence of $\mathrm{Cl}^{-}$ions in solution). As expected, organochlorinated intermediates were identified during the electrochemical degradation of TBH in the presence of $\mathrm{Cl}^{-}$ions in solution, but they were no longer detected at the end of the electrolysis.

Finally, considering all the above results, it can be concluded that the electrochemical degradation of TBH using a BDD anode in the presence of $\mathrm{Cl}^{-}$ions is not advantageous. No significant improvement in the TBH and TOC removal rates, or in the energy expense, is achieved and the formation of undesired organochlorines is a real possibility, determined by how the electrolysis is carried out.

\section{Acknowledgments}

We gratefully acknowledge financial support and scholarships from the São Paulo Research Foundation (FAPESP - grant no. 2008/ 
10449-7), CNPq (specially grant number 487270/2012-6), and CAPES, as well the supply of samples of a commercial formulation of tebuthiuron by the company Adama Brasil S.A.

\section{Appendix A. Supplementary data}

Supplementary data associated with this article can be found, in the online version, at http://dx.doi.org/10.1016/j. electacta.2017.07.054

\section{References}

[1] M.A. Rodrigo, N. Oturan, M.A. Oturan, Electrochemically assisted remediation of pesticides in soils and water: A review, Chem. Rev. 114 (2014) 8720.

[2] S. Mostafalou, M. Abdollahi, Pesticides and human chronic diseases: Evidences, mechanisms, and perspectives, Toxicol. Appl. Pharmacol. 268 (2013) 157.

[3] A.K. Abdessalem, N. Bellakhal, N. Oturan, M. Dachraoui, M.A. Oturan, Treatment of a mixture of three pesticides by photo- and electro-Fenton processes, Desalination 250 (2010) 450.

[4] R.A. Relyea, A cocktail of contaminants: how mixtures of pesticides at low concentrations affect aquatic communities, Oecologia 159 (2009) 363.

[5] M. Muneer, M. Qamar, M. Saquib, D.W. Bahnemann, Heterogeneous photocatalysed reaction of three selected pesticide derivatives, propham, propachlor and tebuthiuron in aqueous suspensions of titanium dioxide, Chemosphere 61 (2005) 457.

[6] M. Panizza, G. Cerisola, Electrochemical degradation of methyl red using BDD and $\mathrm{PbO}_{2}$ anodes, Ind. Eng. Chem. Res. 47 (2008) 6816.

[7] L.S. Andrade, T.T. Tasso, D.L. da Silva, R.C. Rocha-Filho, N. Bocchi, S.R. Biaggio On the performances of lead dioxide and boron-doped diamond electrodes in the anodic oxidation of simulated wastewater containing the Reactive Orange 16 dye, Electrochim. Acta 54 (2009) 2024.

[8] J.M. Aquino, K. Irikura, R.C. Rocha-Filho, N. Bocchi, S.R. Biaggio, A comparison of electrodeposited $\mathrm{Ti} / \mathrm{B}-\mathrm{PbO}$ and $\mathrm{Ti}-\mathrm{Pt} / \mathrm{\beta}-\mathrm{PbO}_{2}$ anodes in the electrochemical degradation of the Direct Yellow 86 dye, Quim. Nova 33 (2010) 2124

[9] E. Brillas, C.A. Martínez-Huitle, Decontamination of wastewaters containing synthetic organic dyes by electrochemical methods. An updated review, Appl. Catal. B: Environ. 166-167 (2015) 603.

[10] A.S. Fajardo, R.C. Martins, C.A. Martínez-Huitle, R.M. Quinta-Ferreira, Treatment of Amaranth dye in aqueous solution by using one cell or two cells in series with active and non-active anodes, Electrochim. Acta 210 (2016) 96.

[11] K. Irikura, N. Bocchi, R.C. Rocha-Filho, S.R. Biaggio, J. Iniesta, V. Montiel, Electrodegradation of the Acid Green 28 dye using Ti $/ 3-\mathrm{PbO}_{2}$ and Ti-Pt $/ \beta-\mathrm{PbO}_{2}$ anodes, J. Environ. Manage. 183 (2016) 306.

[12] F.C. Moreira, R.A.R. Boaventura, E. Brillas, V.J.P. Vilar, Electrochemical advanced oxidation processes: A review on their application to synthetic and real wastewaters, Appl. Catal. B: Environ. 202 (2017) 217.

[13] L. Ciríaco, C. Anjo, J. Correia, M.J. Pacheco, A. Lopes, Electrochemica degradation of Ibuprofen on $\mathrm{Ti} / \mathrm{Pt} / \mathrm{PbO}$ and $\mathrm{Si} / \mathrm{BDD}$ electrodes, Electrochim. Acta 54 (2009) 1464

[14] I. Sirés, E. Brillas, Remediation of water pollution caused by pharmaceutica residues based on electrochemical separation and degradation technologies: A review, Environ. Int. 40 (2012) 212.

[15] L. Feng, E.D. van Hullebusch, M.A. Rodrigo, G. Esposito, M.A. Oturan, Removal of residual anti-inflammatory and analgesic pharmaceuticals from aqueous systems by electrochemical advanced oxidation processes. A review, Chem. Eng. J. 228 (2013) 944.

[16] Y. He, W. Huang, R. Chen, W. Zhang, H. Lin, H. Li, Anodic oxidation of aspirin on $\mathrm{PbO}_{2}$, BDD and porous Ti/BDD electrodes: Mechanism, kinetics and utilization rate, Sep. Purif. Technol. 156 (2015) 124.

[17] D.A.C. Coledam, J.M. Aquino, B.F. Silva, A.J. Silva, R.C. Rocha-Filho, Electrochemical mineralization of norfloxacin using distinct boron-doped diamond anodes in a filter-press reactor, with investigations of toxicity and oxidation by-products, Electrochim. Acta 213 (2016) 856.

[18] C. Salazar, N. Contreras, H.D. Mansilla, J. Yáñeza, R. Salazar, Electrochemica degradation of the antihypertensive losartan in aqueous medium by electrooxidation with boron-doped diamond electrode, J. Hazard. Mater. 319 (2016) 84.

[19] D.A.C. Coledam, M.M.S. Pupo, B.F. Silva, A.J. Silva, K.I.B. Eguiluz, G.R. SalazarBanda, J.M. Aquino, Electrochemical mineralization of cephalexin using a conductive diamond anode: A mechanistic and toxicity investigation, Chemosphere 168 (2017) 638

[20] C. Flox, P.L. Cabot, F. Centellas, J.A. Garrido, R.M. Rodríguez, C. Arias, E. Brillas, Electrochemical combustion of herbicide mecoprop in aqueous medium using a flow reactor with a boron-doped diamond anode, Chemosphere 64 (2006) 892.

[21] M.A.M. Cartaxo, C.M. Borges, M.I.S. Pereira, M.H. Mendonça, Electrochemical oxidation of paraquat in neutral medium, Electrochim. Acta 176 (2015) 1010.

[22] G.F. Pereira, R.C. Rocha-Filho, N. Bocchi, S.R. Biaggio, Electrochemical degradation of the herbicide picloram using a filter-press flow reactor with a boron-doped diamond or $\beta-\mathrm{PbO}_{2}$ anode, Electrochim. Acta 179 (2015) 588
[23] F. Souza, S. Quijorna, M.R.V. Lanza, C. Sáez, P. Cañizares, M.A. Rodrigo, Applicability of electrochemical oxidation using diamond anodes to the treatment of a sulfonylurea herbicide, Catal. Today 280 (2017) 192.

[24] Y.N. Hou, J.H. Qu, X. Zhao, H.J. Liu, Electrochemical incineration of dimethyl phthalate by anodic oxidation with boron-doped diamond electrode, J. Environ. Sci. 21 (2009) 1321.

[25] G.F. Pereira, R.C. Rocha-Filho, N. Bocchi, S.R. Biaggio, Electrochemical degradation of bisphenol A using a flow reactor with a boron-doped diamond anode, Chem. Eng. J. 198-199 (2012) 282.

[26] F.L. Souza, J.M. Aquino, D.W. Miwa, M.A. Rodrigo, A.J. Motheo, Electrochemical degradation of dimethyl phthalate ester on a DSA electrode, J. Braz. Chem. Soc. 25 (2014) 492

[27] G. Coria, I. Sirés, E. Brillas, J.L. Nava, Influence of the anode material on the degradation of naproxen by Fenton-based electrochemical processes, Chem. Eng. J. 304 (2016) 817.

[28] J.M. Peralta-Hernández, C. de la Rosa-Juárez, V. Buzo-Muñoz, J. Paramo-Vargas, P. Cañizares-Cañizares, M.A. Rodrigo-Rodrigo, Synergism between anodic oxidation with diamond anodes and heterogeneous catalytic photolysis for the treatment of pharmaceutical pollutants, Sustainable Environ. Res. 26 (2016) 70.

[29] I.J.S. Montes, B.F. Silva, J.M. Aquino, On the performance of a hybrid process to mineralize the herbicide tebuthiuron using a DSA ${ }^{\mathbb{R}}$ anode and UVC light: a mechanistic study, Appl. Catal. B: Environ. 200 (2016) 237.

[30] E.V. dos Santos, C. Sáez, P. Cañizares, C.A. Martínez-Huitle, M.A. Rodrigo, Treating soil-washing fluids polluted with oxyfluorfen by sono-electrolysis with diamond anodes, Ultrason. Sonochem. 34 (2017) 115.

[31] M. Panizza, G. Cerisola, Application of diamond electrodes to electrochemical processes, Electrochim. Acta 51 (2005) 191.

[32] M. Panizza, G. Cerisola, Direct and mediated anodic oxidation of organic pollutants, Chem. Rev. 109 (2009) 6541.

[33] C.A. Martínez-Huitle, M.A. Rodrigo, I. Sire's, O. Scialdone, Single and coupled electrochemical processes and reactors for the abatement of organic water pollutants: A critical review, Chem. Rev. 115 (2015) 13362.

[34] A. Kapalka, G. Fóti, C. Comninellis, Kinetic modelling of the electrochemical mineralization of organic pollutants for wastewater treatment, J. Appl. Electrochem. 38 (2008) 7.

[35] J. Radjenovic, D.L. Sedlak, Challenges and opportunities for electrochemical processes as next-generation technologies for the treatment of contaminated water, Environ. Sci. Technol. 49 (2015) 11292.

[36] S.T.T. Bicalho, T. Langenbach, The fate of tebuthiuron in microcosm with riparian forest seedlings, Geoderma 207-208 (2013) 66.

[37] M.L.M. Tagert, J.H. Massey, D.R. Shaw, Water quality survey of Mississippi's Upper Pearl River, Sci. Total Environ. 481 (2014) 564.

[38] A.G. Trovó, R. Dalla Villa, R.F.P. Nogueira, Use of photo-Fenton reactions in the prevention of agricultural contaminations, Quim. Nova 28 (2005) 847.

[39] W.C. Paterlini, R.F.P. Nogueira, Multivariate analysis of photo-Fenton degradation of the herbicides tebuthiuron, diuron and 2, 4-D, Chemosphere 58 (2005) 1107.

[40] R.F.P. Nogueira, M.R.A. Silva, A.G. Trovó, Influence of the iron source on the solar photo-Fenton degradation of different classes of organic compounds, Sol. Energy 79 (2005) 384.

[41] M.R.A. Silva, A.G. Trovó, R.F.P. Nogueira, Degradation of the herbicide tebuthiuron using solar photo-Fenton process and ferric citrate complex at circumneutral pH, J. Photochem. Photobiol., A 191 (2007) 187.

[42] M.R.A. Silva, W. Vilegas, M.V.B. Zanoni, R.F.P. Nogueira, Photo-Fenton degradation of the herbicide tebuthiuron under solar irradiation: Iron complexation and initial intermediates, Water Res. 44 (2010) 3745.

[43] W. Bahnemann, M. Muneer, M.M. Haque, Titanium dioxide-mediated photocatalysed degradation of few selected organic pollutants in aqueous suspensions, Cat. Today 124 (2007) 133.

[44] F. Gozzi, I. Sirés, A. Thiam, S.C. de Oliveira, A. Machulek Jr., E. Brillas, Treatment of single and mixed pesticide formulations by solar photoelectro-Fenton using a flow plant, Chem. Eng. J. 310 (2017) 503.

[45] S.A. Alves, T.C.R. Ferreira, M.R.V. Lanza, Electrochemical oxidation of the herbicide tebuthiuron using DSA ${ }^{\mathbb{B}}$-type electrode, Quim. Nova 35 (2012) 1981.

[46] S.A. Alves, T.C.R. Ferreira, N.S. Sabatini, A.C.A. Trientini, F.L. Migliorini, M.R. Baldan, N.G. Ferreira, M.R.V. Lanza, A comparative study of the electrochemical oxidation of the herbicide tebuthiuron using boron-doped diamond electrodes, Chemosphere 88 (2012) 155.

[47] D.A.C. Coledam, J.M. Aquino, R.C. Rocha-Filho, N. Bocchi, S.R. Biaggio, Influence of chlorine-mediated oxidation on the electrochemical degradation of the Direct Black 22 dye using boron-doped diamond and $\beta-\mathrm{PbO}_{2}$ anodes, Quim Nova 37 (2014) 1312.

[48] J. Weber, Ionization of buthidazole VEL 3510, tebuthiuron, fluridone, metribuzin, and prometryn, Weed Sci. 28 (1980) 467.

[49] J.M. Aquino, M.A. Rodrigo, R.C. Rocha-Filho, C. Sáez, P. Cañizares, Influence of the supporting electrolyte on the electrolyses of dyes with conductivediamond anodes, Chem. Eng. J. 184 (2012) 221.

[50] J.M. Aquino, R.C. Rocha-Filho, N. Bocchi, S.R. Biaggio, Electrochemical degradation of the Disperse Orange 29 dye on a $\beta-\mathrm{PbO}_{2}$ anode assessed by the response surface methodology, J. Environ. Chem. Eng. 1 (2013) 954.

[51] S. Aquino Neto, A.R. de Andrade, Electrooxidation of glyphosate herbicide at different DSA ${ }^{\mathbb{B}}$ compositions: $\mathrm{pH}$, concentration and supporting electrolyte effect, Electrochim. Acta 54 (2009) 2039.

[52] G.R.P. Malpass, D.W. Miwa, S.A.S. Machado, P. Olivi, A.J. Motheo, Oxidation of the pesticide atrazine at DSA ${ }^{\sqrt{B}}$ electrodes, J. Hazard. Mater. 137 (2006) 565. 
[53] A. Kapalka, G. Fóti, C. Comninellis, The importance of electrode material in environmental electrochemistry: formation and reactivity of free hydroxyl radicals on boron-doped diamond electrodes, Electrochim. Acta 54 (2009) 2018.

[54] M. Deborde, U. von-Gunten, Reactions of chlorine with inorganic and organic compounds during water treatment-Kinetics and mechanisms: A critical review, Water Res. 42 (2008) 13.

[55] F. Bonfatti, S. Ferro, F. Lavezzo, M. Malacarne, G. Lodi, A. De Battisti, Electrochemical incineration of glucose as a model organic substrate. II. Role of active chlorine mediation, J. Electrochem. Soc. 147 (2000) 592.

[56] C. Flox, E. Brillas, A. Savall, K. Groenen-Serrano, Kinetic study of the electrochemical mineralization of $\mathrm{m}$-cresol on a boron-doped diamond anode, Curr. Org. Chem. 16 (2012) 1960.

[57] P. Cañizares, J. García-Gómez, I.F. de-Marcos, M.A. Rodrigo, J. Lobato, Measurement of mass-transfer coefficients by an electrochemical technique, J. Chem. Educ. 83 (2006) 1204.

[58] M. Panizza, P.A. Michaud, G. Cerisola, C. Comninellis, Anodic oxidation of 2naphthol at boron-doped diamond electrodes, J. Electroanal. Chem. 507 (2001) 206.

[59] M.E.H. Bergmann, J. Rollin, Product and by-product formation in laboratory studies on disinfection electrolysis of water using boron-doped diamond anodes, Cat. Today 124 (2007) 198.
[60] A. Cabeza, A.M. Urtiaga, I. Ortiz, Electrochemical treatment of landfill leachates using a boron-doped diamond anode, Ind. Eng. Chem. Res. 46 (2007) 1439.

[61] A. Anglada, A. Urtiaga, I. Ortiz, Pilot scale performance of the electro-oxidation of landfill leachate at boron-doped diamond anodes, Environ. Sci. Technol. 43 (2009) 2035.

[62] M. Murugananthan, S. Yoshihara, T. Rakuma, T. Shirakashi, Mineralization of bisphenol A (BPA) by anodic oxidation with boron-doped diamond (BDD) electrode, J. Hazard. Mater. 154 (2008) 213.

[63] J.R. Baker, M.W. Milke, J.R. Mihelcic, Relationship between chemical and theoretical oxygen demand for specific classes of organic chemicals, Water Res. 33 (1999) 327.

[64] M. Panizza, A. Barbucci, R. Ricotti, G. Cerisola, Electrochemical degradation of methylene blue, Sep. Purif. Technol. 54 (2007) 382.

[65] P. Cañizares, R. Paz, C. Sáez, M.A. Rodrigo, Electrochemical oxidation of alcohols and carboxylic acids with diamond anodes. A comparison with other advanced oxidation processes, Electrochim. Acta 53 (2008) 2144.

[66] J.M. Aquino, R.C. Rocha-Filho, P. Cañizares, C. Sáez, M.A. Rodrigo, High efficiencies in the electrochemical oxidation of an anthraquinonic dye with conductive-diamond anodes, Environ. Sci. Pollut. Res. 21 (2014) 8442.

[67] E. Brillas, I. Sirés, M.A. Oturan, Electro-Fenton process and related electrochemical technologies based on Fenton's reaction chemistry, Chem. Rev. 109 (2009) 6570. 